\title{
VALIDATION OF TRAINING PRIORITIES OF ENGINEERS IN THE PLATINUM MINING INDUSTRY IN SOUTH AFRICA
}

\author{
D. Motsoeneng ${ }^{1}$, C. Schultz ${ }^{2 *} \&$ A. Bezuidenhout ${ }^{3}$ \\ 1,2Department of People Management and Development \\ Tshwane University of Technology \\ Pretoria, South Africa \\ ${ }^{1}$ Danny.Motsoeneng@avenggroup.com, ${ }^{2}$ SchultzCM@tut.ac.za \\ ${ }^{3}$ Department Human Resource Management \\ University of South Africa \\ Pretoria, South Africa \\ bezuia@tut.ac.za
}

\begin{abstract}
Despite a significant need, there is very little South African research on the validation of the generic training priorities of engineers within the platinum mining industry. The purpose of this study was to validate the generic training priorities of engineers in the platinum mining industry in three provinces in South Africa. For this study, a quantitative research design was used, a four-point Likert-type questionnaire was designed, and a purposive sample was used. The results of this study indicated that theoretical knowledge, technical skills, management skills, and engineering principles are generic training priorities.
\end{abstract}

\section{OPSOMMING}

Ondanks 'n betekenisvolle behoefte is daar min navorsing gedoen in Suid-Afrika oor die validering van generiese opleidingsprioriteite van ingenieurs in die platinum myn industrie. Die doel van die studie was om die geldigheid van die generiese opleidingsprioriteite van platinum myn ingenieurs te ondersoek in drie provinsies in Suid-Afrika. ' $n$ Kwantitatiewe navorsingsmetode was gebruik, 'n vier-punt Likert-tipe vraelys was ontwikkel, en 'n doelgerigte steekproef was gebruik. Die resultate van die studie het getoon dat teoretiese kennis, tegniese vaardighede, bestuursvaardighede en ingenieursbeginsels die generiese opleidingsprioriteite is.

The author was enrolled for an MTech at the Tshwane University of Technology

* Corresponding author 
Through the Skills Development Act of 1998, the South African government has introduced many changes to the continuing professional development of engineers in the country [1]. From the Industrial Training Boards (ITBs), which have defined and specified training mandates in economic sectors, Sector Education Training Boards were introduced; these include the Mining Qualifications Authority (MQA), which extends beyond the industrial base of the country's economy [2]. According to MacCartney [3], the international mining industry faces serious labour scarcities. In addition, the demand for platinum grows consistently [4]. In response to this problem, the current study endeavoured to validate the generic training priorities of engineers in the platinum mining industry in the provinces of the North West, Limpopo, and Gauteng in South Africa.

\section{ENGINEERING SKILLS}

As a result of the existing skills scarcity, it is imperative to reconsider the validity of engineering training courses against the engineering skills demanded by industry [5]. Daniels [6] mentions that many organisations' investments in training fail to yield appropriate returns on investment; Daniels [6] suggests that this is probably due to these organisations failing to align training efforts with their objectives and plans.

The aim of training is to alter people's behaviour [7]. According to Flanagan and Finger [8], learning mostly takes place on the job, especially in the case of engineers, who often gain experience through hands-on training. In addition, it is very important that the development of engineers assists them to cope with continuous technological changes and innovations in their industry.

The demand for appropriately-qualified and trained mining engineers in South Africa is in response to the following trends [9]:

- $\quad$ poor high school education results in a small pool of matriculants who are sufficiently adept at mathematics and science to qualify for engineering courses;

- many qualified engineers are rapidly employed by the business sector;

- transformation policies lead to experienced professionals emigrating; and

- inadequate remuneration.

The evolution of mining engineering needs to keep core technologies. [10]. Sometimes the mining engineer is viewed as the 'jack of all trades and master of none' [11]. According to Van der Merwe [46], a shortage of mining engineers is experienced globally and as a result, more experienced and older 'mentors' who have the knowledge and skills to transfer to younger colleagues are in short supply. Cruise [12] reports alarmingly that in the Englishspeaking world the average age of mining engineers is approaching 60. Despite engineers needing to acquire technical skills, broad generic skills, and profound technical knowledge, a very small number of these skills are taught at universities [13].

Engineering skills can be grouped into technical skills and soft skills. Technical skills refer to production scheduling [14], crushing, grinding, and mineral separation and recovery [15]. Furthermore, skills such as metallurgy, extractive metallurgy, and mineral processing are training priorities [16]. The use of new analytical instruments to process the metal for production and maintain technical support is an essential technical skill [17]. Applying basic knowledge to recover metals from their ores, to refine the metals, to process metals and alloys mechanically, and to protect the metals and alloys against mechanical failure and corrosion using a combination of applied physics and chemistry [16] are skills that should be practised by newly-graduated engineers.

Sound background knowledge of related disciplines such as geology, mining, ventilation, and ergonomics complements meticulous observations in real-life situations [17]. The 
mastery of other technical skills such as mathematics, computing, engineering sciences, and engineering design is also vital for mining engineers [16].

The term 'soft skills' is used to refer the management skills that engineers need, such as business management, interpersonal skills [18], communication skills [19], conflict management, and change management [2]. Mining engineers should also have a sound knowledge of human resource management [17], in addition to leadership skills and decision-making skills [20]. Furthermore, problem solving, personal attitudes, and ethical and professional leadership are seen as training priorities for engineers [21].

According to Saravanan [22], the following soft skills are essential for engineers to perform at optimum levels: communication; critical thinking and problem solving; team work; lifelong learning; information management; entrepreneurship; ethics and moral and professional skills; and leadership. Seat and Lord [23] mention that interviewing, questioning, exchanging ideas, and managing conflict are also vital engineering skills.

According to Male et al. [24], the largest gaps related to skills were in communication, leadership, and social skills [24]. Bodmer et al. [25] identified competency gaps in the areas of communication, time management, problem solving, application of knowledge in the workplace, ability to cope with pressure, and ability to be taught. Communication, teamwork, professional attitudes, engineering commerce skills, problem solving, critical thinking, creativity, and practical engineering skills were perceived as highly important to the work of recognised engineers [26]. Engineering by virtue of its profession is very much 'outcomes-based', meaning that engineering professionals are required to demonstrate competence in their field of specialty [27]. According to Male et al. [28], the generic engineering skill factors are communication, cooperation, self-management, professionalism, resourcefulness, management and leadership, engineering industry, practical engineering, and entrepreneurship. Engineers live in trans-disciplinary environments that are very different from the more traditional teaching environment [29]. Male [30] therefore recommends teaching opportunities such as problem- and project-based learning.

In addition, engineers must possess certain business competencies, such as project management, risk management, and maintenance management [26] because engineering organisations are increasingly required to perform more efficiently with a smaller number of people. To manage this structure, it is essential to comprehend which competencies are needed to compete globally [29] [31]. Harvey [32] observes, for example, that the mining industry needs to develop competencies to meet community needs.

The above literature review indicates that mining engineers must possess specific skills to fulfil their roles, and training programmes need to be designed to address these skills deficiencies. The main objective of the current study was to validate the training priorities of engineers in the platinum mining industry. This objective is reflected in the main problem statement of this study, which referred to the fact that generic training priorities are seldom validated.

The main aim of the research on which this article is based was to validate the generic training priorities of platinum mining engineers in the provinces of the North West, Limpopo, and Gauteng in South Africa. A further objective was to assess whether there are differences between the groups, which were formed by the various demographic variables, with regard to the factors that were identified.

\section{HYPOTHESIS}

In order to achieve the abovementioned objective, the following hypothesis was tested (where training priorities are perceived by the respondents):

$H 1_{1}$ : The training priorities of engineers in the platinum mining industry can be validated. 
According to Wegner [33], the design of a questionnaire is critical for ensuring that the correct research questions are addressed and that accurate and appropriate data is collected for statistical analysis. The questions in the four-point Likert-type questionnaire ( 1 = strongly agree, 2 = agree, 3 = disagree, and 4 = strongly disagree) were derived from the literature review and based on the skills that were identified as necessary for engineers in the platinum mining industry. Only closed-ended questions were posed. Each section had an appropriately-phrased introduction, which was related to the subject covered in that section. Questions were formulated in a straightforward manner in order for respondents easily to grasp what was being asked. The questionnaire was laid out in an uncluttered manner to avoid confusing the respondents. Cronbach's alpha was used to measure the reliability of the questionnaire. Face validity was used by receiving input from several experts in terms of profiling the generic training priorities of engineers in the platinum mining sector.

Permission to conduct the study was obtained from the platinum mining industry in the three provinces under study. The questionnaires were delivered to 300 engineers at five mining houses. After two weeks, the completed questionnaires were gathered and processed.

In this study, principal factor analysis with varimax rotation was performed to validate training priorities. Varimax rotation was used because it gives results that make it easy to identify each variable with a single factor. This study considered factor loadings higher than or equal to .40 as significant. Revelle [34] and Field [35] explain that factor analysis is a multivariate statistical technique for identifying whether there are any correlations between a set of observed variables. The eigenvalue for a given factor indicates the variance in all the variables of that factor. For the purposes of this study, all factors with eigenvalues lower than one were ignored.

Cronbach's alpha coefficient and inter-item correlation coefficients were used to assess the internal consistency of the measuring instruments. Cronbach's alpha coefficient was above .70 for all the factors identified, indicating that all the items measured the same attribute.

\section{RESULTS}

The empirical results are reported below.

\subsection{Descriptive statistics}

The demographic profile of the participants will be discussed first. In this research, the population represented five mining houses in three provinces in South Africa: Rustenburg in the North West (Rustenburg), Burgersfort in Limpopo, and Springs in Gauteng. The sample consisted of five occupational categories of engineers based in the mining sector. A total of 79 participants responded, resulting in a response rate of 26.3 per cent. The majority of the sample comprised 27 mining engineers (34.2\%), 16 geologists (20.3\%), and 15 chemists (19\%). The smallest groups in the sample were nine metallurgists $(15.1 \%)$ and nine chemical engineers $(11.4 \%)$.

The research participants comprised 59 females (76\%) and 19 males (24\%). The majority of the participants (44.3\%) were between 18 and 29 years of age, while the smallest proportion $(21.5 \%)$ of participants were 40 years and older. The older engineers are defined as established engineers with 20 years of experience or more. The new entry-level graduates need practical experience and technical skills, and the transfer of basic skills takes place during job training. The older engineers mentor the junior engineers in the application of the acquired knowledge to the job; these skills are transferred to junior engineers during 'on-the-job' training. Most of the respondents $(35.4 \%)$ had been working at these mining companies for at least five years. The single largest categories in terms of the length of time participants had spent working at these mining companies included those who had worked for more than 10 years $(25.3 \%)$ and those who had worked for less than one 
year $(22.8 \%)$. Only 15.2 per cent of the participants had been employed for six to nine years.

\subsection{Hypothesis testing}

Since parts of the study consisted of small subgroups, it was decided to use non-parametric tests for the hypothesis.

\subsubsection{Testing of hypothesis}

The Kaiser-Meyer-Olkin (KMO) measure of sampling adequacy was 0.648 , and Bartlett's test of sphericity was significant $(\mathrm{p}<0.05)$, which indicated sampling adequacy. As a rule of thumb, KMO should be 0.60 or higher in order to proceed with a factor analysis, but a value of 0.8 or higher is desirable.

Table 1: KMO and Bartlett's test

\begin{tabular}{|l|l|l|}
\hline Kaiser-Meyer-Olkin measure of sampling adequacy & .648 \\
\hline \multirow{3}{*}{ Bartlett's test of sphericity } & Approx. chi-square & 1633.498 \\
\cline { 2 - 3 } & Df & 703 \\
\cline { 2 - 3 } & Sig. & .000 \\
\hline
\end{tabular}

A principal axis factor analysis with a direct oblimin rotation was used. After exploring a number of factor solutions, a three-factor solution was deemed to be the best. These factors explained 44.35 per cent of the variance. The factor matrix with loadings is presented in Table 2.

In order to validate the engineering skills identified, the factor analysis shown in Table 2 was performed. The items that loaded high on each of the three factors were theoretical skills, technical skills, and engineering principles. These three factors are the main validated training priorities.

Table 2: Three-factor analysis results

\begin{tabular}{|c|c|c|c|}
\hline \multirow[b]{2}{*}{ Statement } & \multicolumn{3}{|l|}{ Factor } \\
\hline & $\begin{array}{l}1 \\
\text { Theoretical } \\
\text { skills }\end{array}$ & $\begin{array}{l} \\
\text { Engineering } \\
\text { skills }\end{array}$ & $\begin{array}{l}3 \\
\text { Technical } \\
\text { knowledge }\end{array}$ \\
\hline I know how to perform metal accounting for customers. & .818 & -.208 & \\
\hline I know how to source new equipment. & .730 & & \\
\hline I am competent in project implementation. & .666 & .217 & \\
\hline I know how to commission new analytical instruments. & .657 & -.239 & \\
\hline $\begin{array}{l}\text { I understand the ISO } 14000 \text { (environmental) management } \\
\text { systems. }\end{array}$ & .657 & & \\
\hline I know how to conduct planned maintenance. & .612 & & .283 \\
\hline I understand the ISO 9001 (quality). & .581 & & \\
\hline I perform planned job observations. & .574 & & \\
\hline $\begin{array}{l}\text { I have knowledge of the Basic Conditions of Employment } \\
\text { Act. }\end{array}$ & .562 & .224 & -.267 \\
\hline $\begin{array}{l}\text { I conduct research of new technology in the analytical } \\
\text { field. }\end{array}$ & .527 & & \\
\hline I have knowledge of health and safety regulations. & .505 & & \\
\hline $\begin{array}{l}\text { I possess knowledge of mineral beneficiation or ore } \\
\text { preparation. }\end{array}$ & .491 & .224 & \\
\hline I have an understanding of the treatment of effluents. & .487 & & \\
\hline $\begin{array}{l}\text { demonstrate knowledge of statistical methods in } \\
\text { engineering problem-solving. }\end{array}$ & .464 & & \\
\hline $\begin{array}{l}\text { l have knowledge of the National Environmental } \\
\text { Management Act. }\end{array}$ & .455 & & \\
\hline $\begin{array}{l}\text { I possess knowledge of the mechanical process for ore } \\
\text { processing. }\end{array}$ & .405 & & \\
\hline $\begin{array}{l}\text { I have knowledge of the Mine Health and Safety Act and } \\
\text { the Minerals Act }\end{array}$ & .342 & & \\
\hline $\begin{array}{l}\text { Engineers require combined technical and supervisory } \\
\text { competency skills. }\end{array}$ & .341 & .263 & \\
\hline
\end{tabular}




\begin{tabular}{|c|c|c|c|}
\hline & Factor & Statement & Factor \\
\hline Statement & $\begin{array}{l}1 \\
\text { Theoretical } \\
\text { skills }\end{array}$ & $\begin{array}{l}2 \\
\text { Engineering } \\
\text { skills }\end{array}$ & $\begin{array}{l}3 \\
\text { Technical } \\
\text { knowledge }\end{array}$ \\
\hline $\begin{array}{l}\text { Engineers strive to reach win-win outcomes in conflict } \\
\text { resolution. }\end{array}$ & .323 & -.271 & .238 \\
\hline $\begin{array}{l}\text { possess the knowledge to conduct white area } \\
\text { investigations for mine planning. }\end{array}$ & & .679 & \\
\hline $\begin{array}{l}\text { understand the statistical principles of geological } \\
\text { sampling. }\end{array}$ & & .662 & \\
\hline $\begin{array}{l}\text { I am equipped with the skills to identify hazards } \\
\text { associated with geotechnical areas. }\end{array}$ & -.274 & .644 & .407 \\
\hline I possess knowledge of underground drilling processes. & -.359 & .611 & .359 \\
\hline $\begin{array}{l}\text { I have sufficient interpersonal skills with all levels of } \\
\text { mining personnel }\end{array}$ & & .607 & \\
\hline I possess knowledge of software applications. & & .596 & -.307 \\
\hline I have the ability to lead mining personnel. & .214 & .533 & \\
\hline I have an understanding of geological mapping. & & .526 & \\
\hline $\begin{array}{l}\text { I understand the statistical principles of environmental } \\
\text { sampling. }\end{array}$ & .423 & .448 & \\
\hline I have an understanding of mineral/ore crushing. & .272 & .287 & \\
\hline I have knowledge of explosives prevention. & & & .868 \\
\hline I am knowledgeable about controlled or distress blasting. & & .212 & .822 \\
\hline $\begin{array}{l}\text { I have an understanding of the haulage management } \\
\text { process }\end{array}$ & & .332 & .696 \\
\hline I have a blasting certificate. & & & .682 \\
\hline $\begin{array}{l}\text { I am familiar with the basic support principles of rock } \\
\text { engineering. }\end{array}$ & -.355 & .511 & .596 \\
\hline I supervise construction of major engineering works. & & & .478 \\
\hline $\begin{array}{l}\text { Engineers are trained in principles and techniques of } \\
\text { analysing complex deformed geological terrains. }\end{array}$ & & & .416 \\
\hline
\end{tabular}

The research objective was investigated to determine whether the priority training needs of engineers could be validated. A list of training priorities was developed by integrating the literature review and the empirical results; these are presented in Table 3.

Goldstein and Ford [36] acknowledge that various needs assessment models exist. However, the gap between engineers having these skills and engineers acquiring these skills involves a system of personnel operation that provides opportunities for engineers to acquire the required skills [5].

Previous research showed that training priorities are often approached informally and unsystematically, with most organisations relying a great deal on decisions made by top management. These decisions are made to invest in engineers [37-41] and Human Resource (HR) managers are often tasked with overseeing the implementation of these decisions.

This research will add value by contributing to a comprehensive understanding of the knowledge gaps and competency requirements of platinum mining engineers; this knowledge is key to maintaining profitability and sustainability in the platinum mining industry. Wagonhurst [42] suggests that determining training priorities relates to the complexity of the skills of engineers. The objectives behind conducting training priorities could prove useful in reaching the organisational goals by closing the gaps through successful training [43]. However, the identification of training priorities should not be given to inexperienced trainers and supervisors [44].

\subsubsection{Reliability testing}

Cronbach's alpha of 0.7 or higher indicates reliability of the questionnaire. These tests were performed in order to validate the training priorities identified in this study.

Table 4 illustrates Cronbach's alpha coefficient for theoretical skills of engineers. 
Table 3: Training priorities of platinum mining engineers

\begin{tabular}{|l|l|}
\hline TRAINING PRIORITY & KEY ACTIVITIES \\
\hline \multirow{5}{*}{ Theoretical knowledge } & Metal accounting \\
& Project management \\
& Environmental management \\
& Occupational Health and Safety Act \\
& Mine Health and Safety Act \\
& Supervisory skills \\
& ISO quality standards \\
& Basic Conditions of Employment Act \\
& National Environmental Management Act \\
& Conflict management \\
\hline & Sampling \\
& Risk assessment \\
& Drilling process \\
& Interpersonal skills \\
& Ore crushing \\
Technical and management skills & Chemistry \\
& Extractive metallurgy \\
& Rock blasting \\
& Production scheduling \\
& Leadership skills \\
& Communications skills \\
& Mineral separation and analysis \\
& Computer software application \\
\hline \multirow{5}{*}{ Engineering principles } & Blasting certificate \\
& Haulage and loading \\
& Rock engineering \\
\hline
\end{tabular}

Table 4: Knowledge and theoretical skills

\begin{tabular}{|l|l|l|}
\hline & $\begin{array}{l}\text { Squared multiple } \\
\text { correlation }\end{array}$ & $\begin{array}{l}\text { Cronbach's alpha if item } \\
\text { deleted }\end{array}$ \\
\hline I know how to perform metal accounting for customers. & .636 & .874 \\
\hline I know how to source new equipment. & .729 & .873 \\
\hline I am competent in project implementation. & .636 & .876 \\
\hline I know how to commission new analytical instruments. & .707 & .876 \\
\hline $\begin{array}{l}\text { I understand the ISO 14000 (environmental) } \\
\text { management systems. }\end{array}$ & .698 & .875 \\
\hline I know how to conduct planned maintenance. & .699 & .876 \\
\hline I understand the ISO 9001 (quality). & .687 & .877 \\
\hline I perform planned job observations. & .472 & .879 \\
\hline $\begin{array}{l}\text { I have knowledge of the Basic Conditions of Employment } \\
\text { Act. }\end{array}$ & .571 & .881 \\
\hline $\begin{array}{l}\text { I conduct research of new technology in the analytical } \\
\text { field. }\end{array}$ & .609 & .881 \\
\hline I have knowledge of health and safety regulations. & .598 & .881 \\
\hline $\begin{array}{l}\text { I possess knowledge of mineral beneficiation or ore } \\
\text { preparation. }\end{array}$ & .524 & .885 \\
\hline $\begin{array}{l}\text { I have an understanding of the treatment of effluents. } \\
\text { I demonstrate knowledge of statistical methods in } \\
\text { engineering problem-solving. }\end{array}$ & .501 & .385 \\
\hline $\begin{array}{l}\text { I have knowledge of the National Environmental } \\
\text { Management Act. }\end{array}$ & .473 & .880 \\
\hline $\begin{array}{l}\text { I possess knowledge of the mechanical process for ore } \\
\text { processing. }\end{array}$ & .478 & .881 \\
\hline $\begin{array}{l}\text { I have knowledge of the Mine Health and Safety Act and } \\
\text { the Minerals Act. }\end{array}$ & .407 & .882 \\
\hline $\begin{array}{l}\text { Engineers require combined technical and supervisory } \\
\text { competency skills. }\end{array}$ & .398 \\
\hline $\begin{array}{l}\text { Engineers strive to reach win-win outcomes in conflict } \\
\text { resolution. }\end{array}$ & .428 & \\
\hline
\end{tabular}

The scales for knowledge and theoretical skills show a high reliability of 0.886 . All items on the scales contribute well to the overall reliability. 
Table 5 illustrates the item scales for the technical and management skills factor of engineers.

The reliability of the technical and management skills indicates a high reliability of 0.838 . All items on the scales contribute well to the overall reliability. Table 6 illustrates the item scales for the engineering principles.

The reliability of engineering principles is high, which indicates acceptable reliability. The internal consistency of the eight items is 0.847 .

Table 5: Technical and management skills

\begin{tabular}{|l|l|l|}
\hline & $\begin{array}{l}\text { Squared } \\
\text { multiple } \\
\text { correlation }\end{array}$ & $\begin{array}{l}\text { Cronbach's } \\
\text { alpha if item } \\
\text { deleted }\end{array}$ \\
\hline $\begin{array}{l}\text { I possess the knowledge to conduct white area investigations for } \\
\text { mine planning. }\end{array}$ & .507 \\
\hline I understand the statistical principles of geological sampling. & .609 & .808 \\
\hline $\begin{array}{l}\text { I am equipped with the skills to identify hazards associated with } \\
\text { geotechnical areas. }\end{array}$ & .607 & .811 \\
\hline $\begin{array}{l}\text { I possess knowledge of underground drilling processes. } \\
\text { I have sufficient interpersonal skills with all levels of mining } \\
\text { personnel. }\end{array}$ & .625 & .814 \\
\hline I possess knowledge of software applications. & .313 & .820 \\
\hline I have the ability to lead mining personnel. & .423 & .833 \\
\hline I have an understanding of geological mapping. & .450 & .824 \\
\hline I understand the statistical principles of environmental sampling. & .494 & .833 \\
\hline I have an understanding of mineral/ore crushing. & .106 & .848 \\
\hline
\end{tabular}

Table 6: Engineering principles

\begin{tabular}{|l|l|l|}
\hline & $\begin{array}{l}\text { Squared } \\
\text { multiple } \\
\text { correlation }\end{array}$ & $\begin{array}{l}\text { Cronbach's } \\
\text { alpha if item } \\
\text { deleted }\end{array}$ \\
\hline I have knowledge of explosive prevention. & .672 & .801 \\
\hline I am knowledgeable about controlled or distress blasting. & .787 & .787 \\
\hline I have an understanding of the haulage management process. & .623 & .810 \\
\hline I have a blasting certificate. & .454 & .822 \\
\hline I am familiar with the basic support principles of rock engineering. & .545 & .822 \\
\hline I supervise construction of major engineering works. & .172 & .860 \\
\hline $\begin{array}{l}\text { Engineers are trained in principles and techniques of analysing } \\
\text { complex deformed geological terrains. }\end{array}$ & .867 \\
\hline
\end{tabular}

\section{CONCLUSIONS AND RECOMMENDATIONS}

This study made use of a completely new questionnaire to identify the validated training priorities of platinum mining engineers in South Africa. By means of factor analysis, the following factors relating to commitment were extracted: theoretical needs, technical and management skills, and engineering principles.

This study offers insight into the complexities that should be considered when the training needs of engineers are considered. Furthermore, the empirical results highlighted the wide spectrum of training needs of engineers in the mining industry that deserve attention. When integrating the findings of this study with the existing literature, it becomes clear that engineering management practices could be improved by developing the management potential of every platinum mining engineer.

This research will add value by contributing to a comprehensive understanding of the knowledge gaps and competency requirements of platinum mining engineers, as they are key to maintaining profitability and sustainability in the platinum mining industry. Wagonhurst [42] suggests that training priorities relate to the complexity of the skills of engineers. The objectives behind conducting a training priorities audit could prove useful in identifying discrepancies between employee skills and the skills required for effective job performance [43]. The challenge is to develop skills and to increase knowledge in order to 
convert challenges into opportunities. It is not effective to leave training priority identification in the hands of those who have no experience or training on how to identify training priorities [44].

\subsection{Recommendations}

Training priorities must be identified by performing three levels of analysis: organisational, operational, and individual. According to Opperman and Meyer [44], training can be done at different levels: macro level (classification of key skills shortages and assessment), meso level (investigating organisational goals and problems), and micro level (examining tasks performed and the necessary requirements).

It is therefore recommended that the training priorities of engineers in the platinum mining industry also be analysed at the macro and meso level. Studies could also be conducted in other types of mining industries nationally and internationally. Lastly, it is strongly advised that HR managers focus on these priorities when training programmes are designed and implemented for engineers in the platinum mining industry.

\subsection{Shortcomings of the study}

Several limitations were experienced by the researchers during the data-gathering phase. These included the fact that some mining houses refused to take part in the survey because they were concerned with issues of confidentiality. Some of the engineers also indicated that they did not have the time to complete the research questionnaire. The population and sample size could have been larger, considering the population size and statistical techniques employed.

\subsection{Conclusion}

The empirical results of this study indicated that theoretical knowledge, technical skills, management skills, and engineering principles are training priorities for engineers in the platinum mining industry in South Africa. Research in the mining industry has declined, and so it is essential that research is stimulated to generate relevant knowledge and practices [4]. In order to determine the training priorities, further research should be conducted to compare the skills competencies of South African engineers against those of engineers from international mining companies. Research in the mining industry of South Africa is vital to sustain its viability [45]. Mining research should therefore be revived. Similar research could assist other industrial sectors that are experiencing skills shortages, so that all sectors can learn from the research and apply recommended strategies to address skills shortages or the lack of competencies.

In summary, the study reported here was successful in achieving the research aim, which was to validate the training priorities required for engineers in the platinum mining industry.

\section{REFERENCES}

[1] Department of Labour, South Africa. 1998. The Skills Development Act No. 97 of 1998, Government Printers.

[2] Mining Qualifications Authority. 2009. Sector skills plan for the mining \& minerals. Johannesburg: Skills Development and Research.

[3] MacCartney, A. 2008. Skills shortage in the international mining industry now at critical levels. Ernst \& Young.

[4] Van der Merwe, J.N. 2011. Future of the South African mining industry and the roles of the SAIMM and the universities. Journal of the Southern African Institute of Mining and Metallurgy, 111(9), pp. 581-592.

[5] Duns, N. \& Smith, J.V. 2007. Untangling skills and qualifications: Training engineers and related professionals capable of filling skill gaps in the mining industry. Proceedings of the 18th conference of the Australasian Association for Engineering Education, 9-13 December, Melbourne.

[6] Daniels, S. 2003. Employee training: A strategic approach to better returns on investment. The Journal of Business Strategy, 24(5), pp. 39-42.

[7] McClelland, S.D. 2002. A training needs assessment for the united way of Dunn County Wisconsin. Graduate School, University of Wisconsin-Stout.

[8] Flanagan, N. \& Finger, J. 2000. Just about everything a manager needs to know in South Africa. NBD. 
[9] Mthethwa, B. 2009. Crisis in engineering skills. The Times. Retrieved from www.trac.sun.ac.za/images/.../Crisis\%20in\%20engineering\%20skills

[10] Scoble, M. 2009. A new view on the professional nature of mining engineering in society. International Journal of Mining, Reclamation and Environment, 23(4), pp. 239-240.

[11] Costa, S. \& Scoble, M. 2006. A multidisciplinary approach to integrating sustainable development into mining engineering. Journal of Cleaner Production, 14, pp. 366-373.

[12] Cruise, J.A. 2011. The gender and racial transformation of mining engineering in South Africa. Journal of the Southern African Institute of Mining and Metallurgy, 111(4), pp. 217-224.

[13] Trevelyan, J.P. 2008. Early career learning by novice engineers. School of Mechanical Engineering, University of Western Australia.

[14] Kazakidis, V.N. \& Scoble, M. 2003. Planning for flexibility in underground mine production systems. Mining Engineering, 55(8), pp. 33-39.

[15] South African Qualifications Authority. 2009. National Qualifications Framework.

[16] Pistorius, P.C. 2003. The role of a department of metallurgical engineering in the South African metallurgical industry. The Journal of the South African Institute of Mining and Metallurgy, 103(10), pp. 601-606.

[17] Anglo Platinum Careers. 2012. Careers in Anglo American Platinum Limited. Retrieved from www.angloplatinum.com/careers/careers_ang/careers.asp

[18] Seethamraju, R. \& Agrawal, R. 1999. Engineers as managers: A conceptual model of transition. In Management of Engineering and Technology, Technology and Innovation Management. PICMET '99. Portland International Conference, Portland, pp. 293-297.

[19] Trevelyan, J.P. 2007. Technical coordination in engineering practice. Journal of Engineering Education, 96(3), pp. 191-204.

[20] Handley, M.F., Van der Merwe, J.N. \& Werber-Youngman, R.C.W. 2005. Training strategy for mining engineers. Paper presented at the meeting of the University of Iran Mining Engineering Conference, Tehran.

[21] Ismail, N.A., Haron, F., Manaf, K.A. \& Mamat, R. 2001. The importance of non-technical skills in accounting graduates. Akauntan Nasional, pp. 22-27.

[22] Saravanan, V. 2006. Sustainable employability skills for engineering professionals. The Indian Review of World Literature in English, 5.

[23] Seat, E. \& Lord, S.M. 1999. Enabling effective engineering teams: A program for teaching interaction skills. The Research Journal for Engineering Education, 88(4), pp. 385-390.

[24] Male, S.A., Bush, M.B. \& Chapman, E.S. 2010. Perceptions of competency deficiencies in engineering graduates. Australasian Journal of Engineering Education, 16(1), pp. 55-67.

[25] Bodmer, C., Leu, A., Mira, L., \& Ruitter, H. 2002. Successful practices in International Engineering Education. SPINE final report, Benchmarking Study, Zurich. Initial partners: Engineers Shape our Future, Zurich, and Rat der Eidgenössischen Technischen Hochschulen (ETHRat).

[26] Male, S.A., Bush, M.B. \& Chapman, E.S. 2009. Identification of competencies required by engineers graduating in Australia. Proceedings of the 20th Conference on Generic Engineering Competencies. School of Mechanical Engineering, The University of Adelaide, Adelaide, pp. 882887.

[27] Du Toit, R. \& Roodt, J. 2008. Engineers in a developing country: The profession and education of engineering professionals in South Africa. Cape Town: HSRC Press.

[28] Male, S.A., Bush, M.B. \& Chapman, E.S. 2011. Understanding generic engineering competencies. Australasian Journal of Engineering Education, 17(3), pp. 147-156.

[29] Allan, M. \& Chisholm, C.U. 2008. The development of competencies for engineers within a global context. The Higher Education Academy Engineering Subject Centre and the UK Centre for Materials Education.

[30] Male, S.A. 2010. Generic engineering competencies: A review and modelling approach. Education Research and Perspectives, (37), pp. 25-51.

[31] Coates, G., Thompson, C., Duffy, A., Hills, B. \& Whitfield, I. 2009. Modelling skill competencies in engineering companies. Engineering Designer.

[32] Harvey, B. 2002. New competencies in mining: Rio Tinto's experience. Proceedings of the Congress of Mining and Metallurgical Institutions Conference on International Codes, Technology and Sustainability for the Minerals Industry, Cairns, pp. 27-28.

[33] Wegner, T. 2002. Applied business statistics. Juta.

[34] Revelle, W. 2008. Principal axis factor analysis. Retrieved from http://www cran.rproject.org/web/packages/psych/psych.pdf

[35] Field, A. 2009. Discovering statistics using SPSS. Sage.

[36] Goldstein, I.L. \& Ford, K.J. 2002. Training in organisations: Needs assessment, development and evaluation. Wadsworth Thomson Learning.

[37] Agnaia, A.A. 1996. Assessment of management training needs and selection for training: The case of Libyan companies. International Journal of Manpower, 17(3), pp. 31-51.

[38] Amos-Wilson, P. 1996. Management training in UK NGOs: A small survey. Journal of European Industrial Training, 20(1), pp. 15-19.

[39] Elbadri, A.N.A. 2001. Training practices of Polish companies: An appraisal and agenda for improvement. Journal of European Industrial Training, 25(2), pp. 69-79. 
[40] Erffmeyer, R.C., Russ, K.R. \& Hair, J.F. 1991. Needs assessment and evaluation in sales-training programs. Journal of Personal Selling and Sales Management, 11(1), pp. 17-31.

[41] Moore, M.L. \& Dutton, P. 1978. Training needs analysis: Review and critique. Academy of Management Review, 3, pp. 532-545.

[42] Wagonhurst, C. 2002. Effective training programs. Journal of Research Administration, 33(3), pp. 77-81.

[43] Brown, J. 2002. Training needs assessment: A must for developing an effective training program. Public Personnel Management, 31(4), pp. 569-577.

[44] Opperman, C. \& Meyer, M. 2008. Integrating training needs analysis, assessment and evaluation: Aligning learning with business results. Knowledge Resources.

[45] Van der Merwe, J. N. 2011. Future of the South African mining industry and the roles of the SAIMM and the universities. Journal of the Southern African Institute of Mining and Metallurgy, $111(9)$, pp. 581-592. 